症例

同側乳腺に紡錘細胞癌と非浸潤性乳管癌を併発した 1 例

取手北相馬保健医療センター医師会病院外科, 日本大学医学部乳腺内分泌外科* 吉田直白田保夫鈴木武樹谷貞弓*

同側同時性に紡錪細胞癌と非浸潤性乳管癌を併発した症例を経験したので報告する。 症例は54歳, 女性で左乳房腫瘤を主訴に来院した。左乳房に径 $2.5 \mathrm{~cm}$ の無痛性の腫疽を 触知した。 マンモグラフィでも同部に径 $3.4 \mathrm{~cm}$ の境界明瞭平滑な腫溜を認め, 同時に B 領域にも径 $1.1 \mathrm{~cm}$ の淡い石灰化を伴う境界不明瞭な腫瘤を認めた. 乳房超音波検査や夕゙ イナミック MRIでも両腫瘍の性格は明らかに異なっており, 穿刺吸引細胞診では主病 巣である CA 領域が class IIIb, B 領域が class Vであった. 同時性多発乳癌と診断し, 胸筋温存乳房切除術 $(\mathrm{Bt}+\mathrm{Ax}$ )を施行した。病理学的には CA 領域の腫瘍が紡鍾細胞癌 で B 領域の腫瘍が非浸潤性乳管癌であった。特殊型の浸潤癌でも多発乳癌の可能性を念 頭に置く必要があると考えられた。

卖引用語：紡錘細胞癌，非浸潤性乳管癌，多発乳癌

\section{はじめに}

多発乳癌は稀ではないが，単発癌の場合と同様に主 癌巣が特殊型のものは少ない.今回われわれは紡鍾細 胞癌と非浸潤性乳管癌を同側同時性に認めた稀な症例 を経験したので,若干の文献的考察を加えて報告する.

\section{症 例}

患者：54歳, 女性, 閉経後.

主訴: 左乳房腫㾇。

既往歴：17年前より肝血管腫を指摘， 4 年前より高 血圧で内服加療されている.

家族歴：特記すべきことなし.

現病歴: 平成 17 年 2 月の初旬より左乳房の腫瘤を自 己触知するようになり，2 月28日に当院の外科外来を 受診した.

局所所見：左 $\mathrm{CA}$ 領域に $2.5 \mathrm{~cm}$ 大の無痛性の腫瘤 を触知する，弾性硬，表面平滑で可動性は良好．腋窩 のリンパ節は触知せず.

血液検査所見：異常所見なく, 腫場マーカーも CA15-3 4.2U/ml, NCC-ST-439 2.5LTU/ml と正常 範囲内であった。

マンモグラフィ: 左 CA 領域に, $3.4 \times 2 \mathrm{~cm}$ の分葉

2005 年 7 月 22 日受付 2005 年 9 月15日採用

〈所属施設住所〉

テ302-0032 取手市野々井1926
状，境界明瞭平滑で石灰化を伴わない腫瘍を認め，力 テコリリー 3 とした. さらに, 左 B 領域に $1 \times 0.5 \mathrm{~cm}$ の 棈円形，境界不明瞙で集簇性，淡く不明瞭な石灰化を 伴う腫瘤を認めカテゴリー4とした（図 1 ).

乳房超音波所見：左 CA 領 域の腫瘍は $30.4 \times 12.2$ $\mathrm{mm}$ で境界明瞭粗鈢, 前方乳腺境界の断裂を認めず力 テゴリー 3 とした。 左 B 領域の腫場は5.1×5.3mm て 境界不明瞭, 前方乳腺境界の断裂を認めカテゴリー4 とした（図 2 )。両腫瘍間に連続性は認めなかった。

乳房カドリニウム造影 MRI：CA 領域の腫瘍は $32 \times 18 \mathrm{~mm}$ で, T1強調像で等信号, T2強調像で高信 号, 辺緑不鮮明であった. B 領域の腫場 $8 \mathrm{~mm}$ 大で, T1強調像で等信号, T2強調像でやや高信号であった。 またダイナミック撮影では，CA 領域の腫愓は急速に 造影され，覀性を示唆する所見であった，B 領域の腫 瘍は CA 領域の腫湯に比べて徐々に造影され，両腫汮 の造影パターンは異なっていた（図 3 ).

穿刺吸引細胞診：CA 領域の腫場は計 2 回施行し class IIIbであった．B 領域の腫瘍は class Vで浸潤性 乳管癌と診断された。

$\mathrm{CA}$ 領域の腫場は画像所見， $\mathrm{B}$ 領域の腫瘍は穿刺吸 引細胞診より共に乳癌と診断し， 3 月16日に胸筋温存 乳房切除術 $(\mathrm{Bt}+\mathrm{Ax})$ を施行した. 肉眼的にはリンパ 節転移を認めなかった。

切除標本：CA 領域の腫場は $22 \times 16 \mathrm{~mm}$, 弾性硬の 


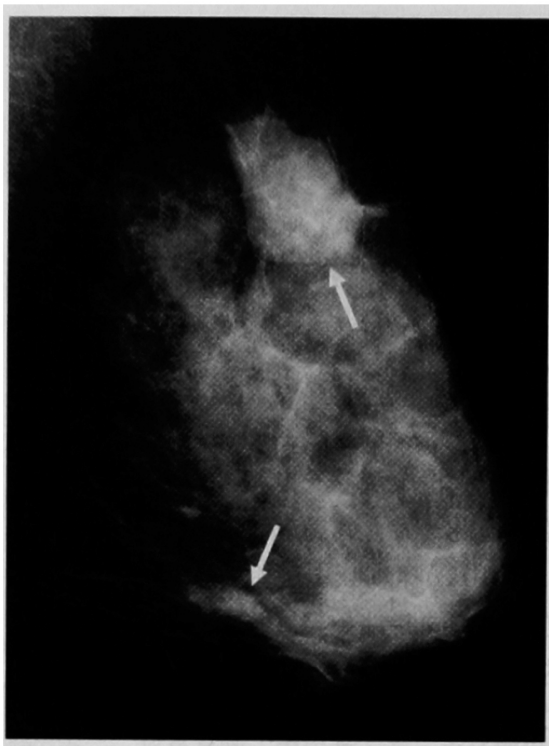

図1 マンモグラフィ:左 CA 領域に長径 $3.4 \mathrm{~cm}$ の分莱状, 境界明䁻平滑な腫癌を認 め, 左 B 領域に長径 $1 \mathrm{~cm}$ の淡い石灰化を 伴う境界不明瞭な腫瘤を認めた。

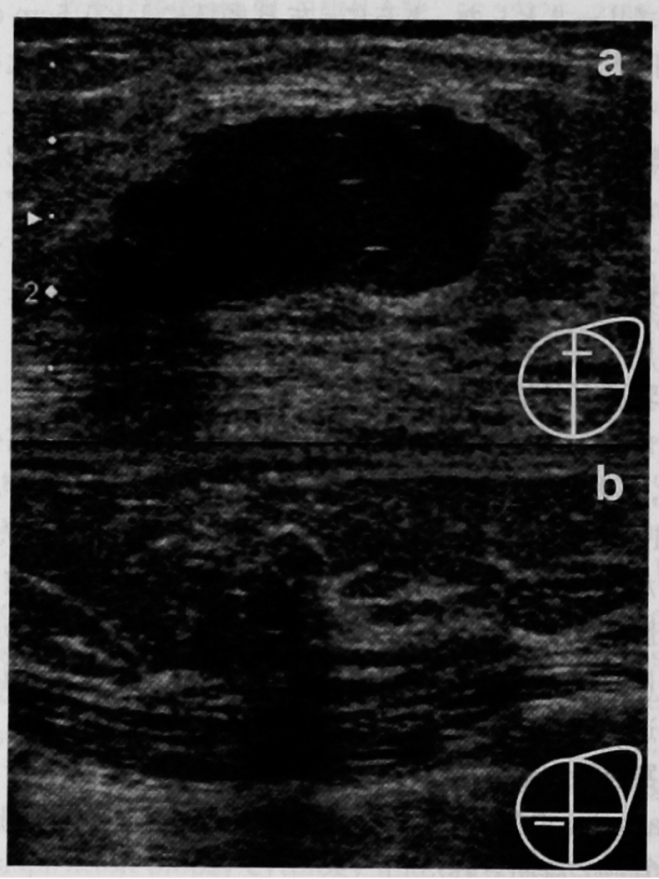

图 2 乳房超音波検查 ( $\mathrm{a}: \mathrm{CA}$ 領域腫浧, b : B 領 域腫瘍）：a）左 CA 領域に $30.4 \times 12.2 \mathrm{~mm}$ の腫瘍 を認めた. b)左 B 領域に5.1×5.3mm の腫暍を認 め, 両者の連続性はなかった。

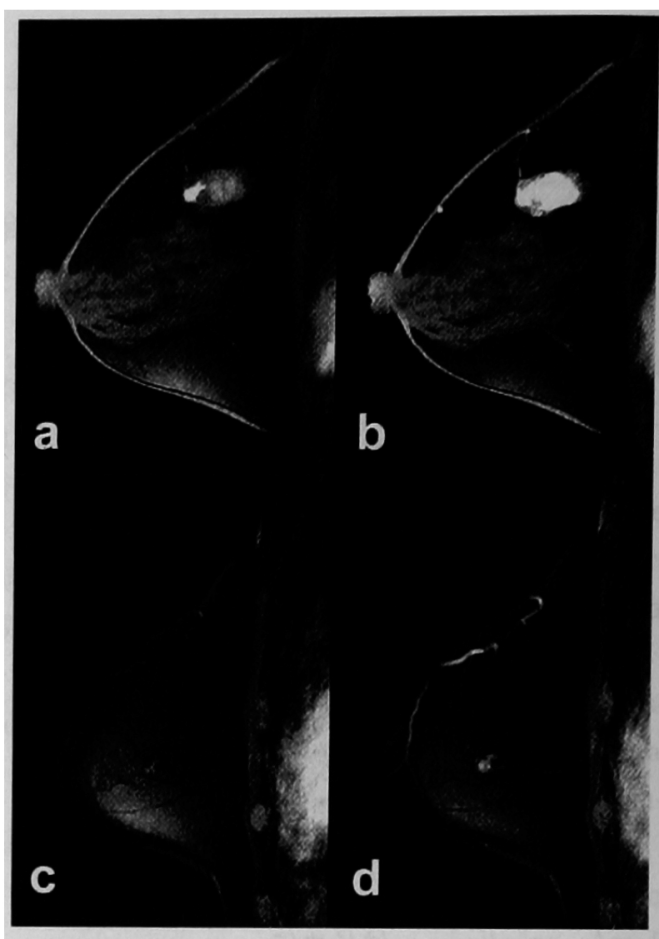

図 3 乳房ダイナミック MRI：a，b）CA 領域の 腫瘍は早期より造影された. c , d) B 領域の腫疸 はCA 領域の腫疸に比べて徐々に造影された。

白色充実性であった，B領域の腫瘍は $8 \times 6 \mathrm{~mm}$ で境 界不明瞭，一部に石灰化を認めた（図4).

組織学的所見：CA 領域の腫演は $2 \times 2 \times 2 \mathrm{~cm}$, 紡 鏵型の細胞を認め肉腫様で,一部に上皮の悪性化を伴 っており，紡錘細胞癌と診断した，B領域の腫瘍は $0.7 \times 0.5 \times 0.7 \mathrm{~cm}$ の非浸潤性乳管癌であった（図 5 ). リンパ節転移は認めず, 病期は T1cN0M0 stage I (TNM 分類) であった.

$\mathrm{CA}$ 領域の腫湯は ER と PgR がともに陰性であっ たが, B 領域の腫痬は $\mathrm{ER}, \mathrm{PgR}$ ともに陽性であった。 HER2過剩発現は両腫瘍ともに認めなかった。

免疫組織染色：CA 領域の腫瘍は上皮系のマーカー である cytokeratin 染色で弱陽性，非上皮系のマーカ ーである vimentin 染色では強陽性であった（図6). 考察

乳腺の紡鍾細胞癌は乳癌取扱い規約では浸潤癌の特 殊型に分類され，その頻度は乳癌のなかで $0.1 \%$ と稀な 組織型である"．定義は「紡鐄細胞からなり肉腫様に見 えるが，一部に上皮性性格の明らかな癌細胞巣や扁平 上皮化生を示す部分がみられることが多く, 肉腫様部 


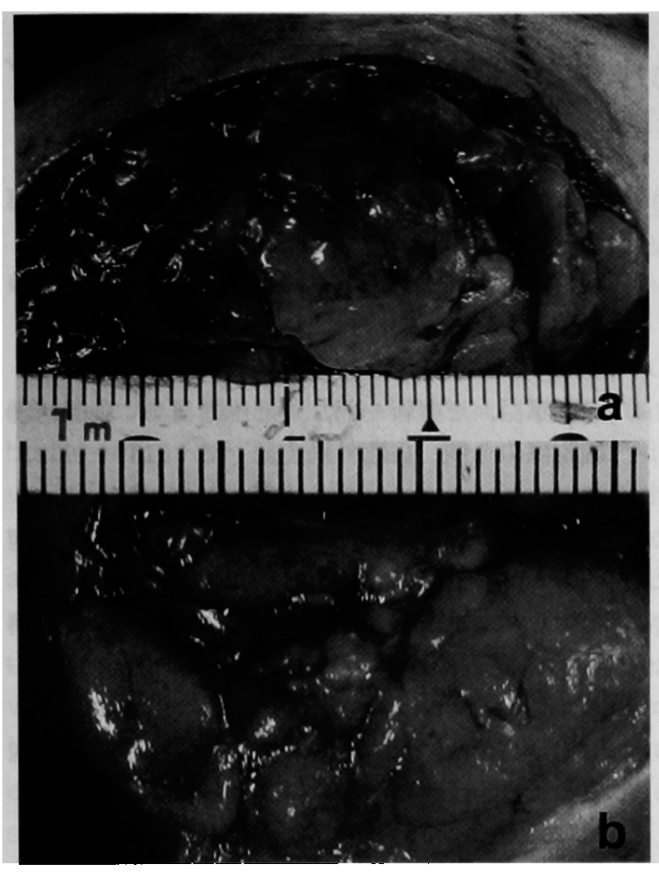

図 4 肉眼所見 ( $a ： C A$ 領域腫瘍, b : B 領域腫 癌)：a ）CA 領域の腫瘍は $22 \times 16 \mathrm{~mm}$, 弾性硬で白 色充実性. b ) B 領域の腫瘍は $8 \times 6 \mathrm{~mm}$ て境界不 明暸，一部に石圧化を認めた。

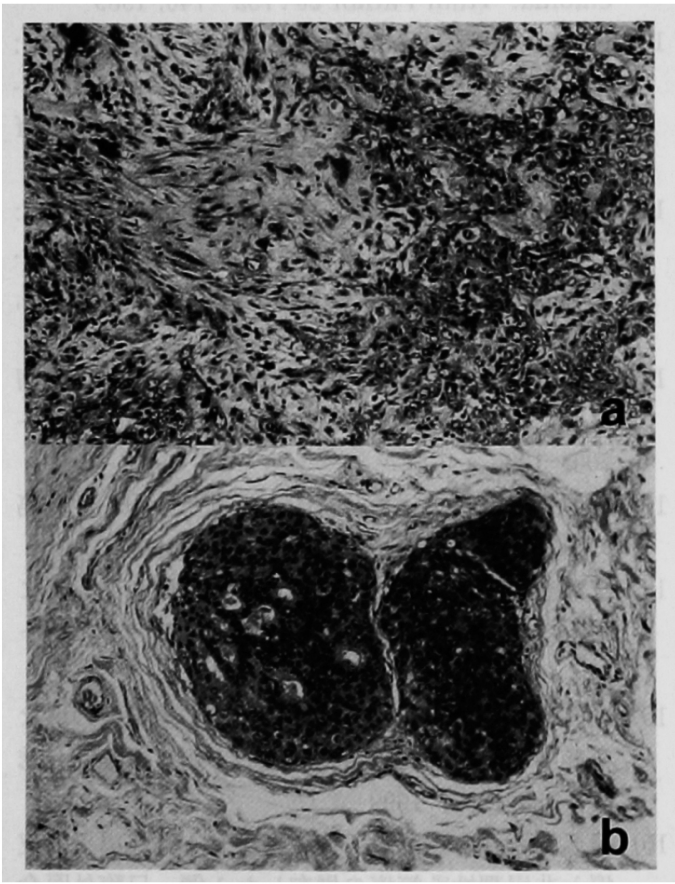

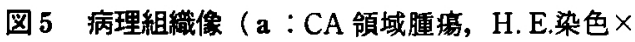
40, b : B 領域腫瘍, H. E.染色 $\times 40$ )

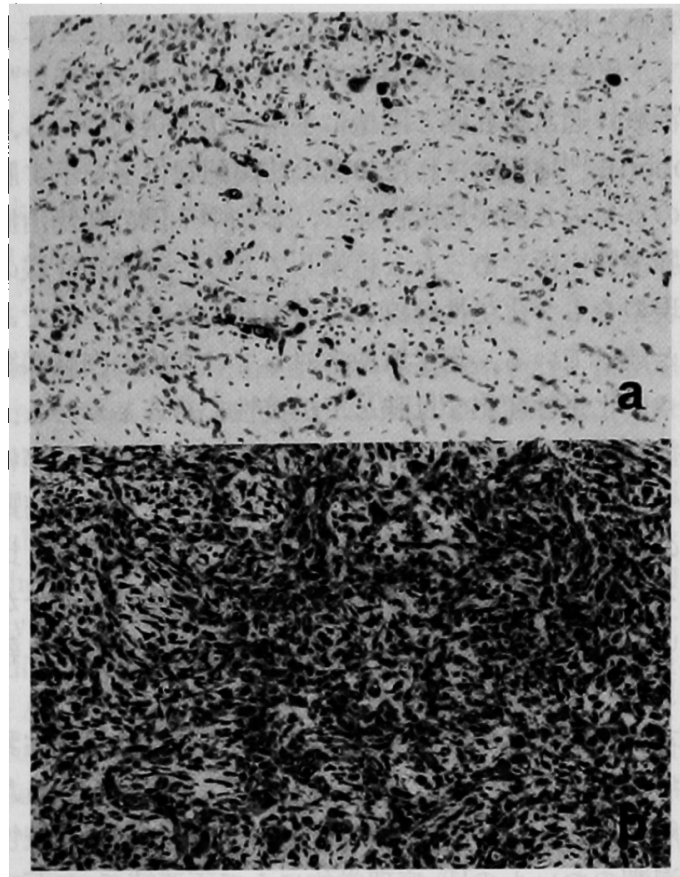

図 6 免疫組織染色 ( a : CA 領域腫瘍, cytokeratin 染色 $\times 40, b: C A$ 領域腫瘍, vimentin 染色 $\times 40$ )

分も上皮性の癌紐胞が紡錘形となったものである」と される2!.規約上の「結合織性および上皮性腫瘍」に分 類される癌肉腫との鑑別のポイントは癌腫と肉腫部分 に移行像を認めないこと, 免疫染色では癌腫部分と肉 腫部分で明確に色分けされること，などである3．

術前に組織型を確定することは困難であるが, 特徴 としては震胞形成があげられ，その頻度を鉿間ら゙は $34 \%$, 康ら゙は $41 \%$ と報告している。これは腫瘍の増殖 速度が速いため, 中心部の血管新生が追いつかず変 性・壞死に楩るためと考えられている。また堌殖速度 に関連して，腫瘍径が大きなものが多く，T3以上の割 合が40.2 45\%と報告している ${ }^{4) 6}$. 自験例では堡胞形 成は認めなかったが，これは腫湯径が小さいためと考 えられた．画像上マンモグラフィで特徴的な所見はな

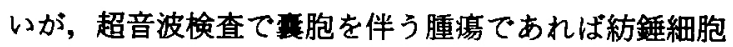
癌も疑うことが重要である.MRIでは，犦胞内で出血 を認めれば同部は $\mathrm{T} 1$ 強調像で高信号を呈し, 腫瘍と の間に fluid-fluid level を形成するとされている.

リンパ節転移の陽性率は20３2\%であり，浸潤性乳 管癌と比べると腫瘍径の大きさの割合にリンパ節転移 は低率である ${ }^{4) 577 . ~}$

エストロゲンレセプターの陽性率は 6 ～25\%で, 通常 
型乳瘦と比べて陰性例が多く,これは紡鏩細胞化生によ って上皮性の性格が失われたためと考えられているいー99. 治療は通常型乳癌と同様に手術療法が選択される. Gobbi ら ${ }^{10}$ は切除された30例の紡鍾細胞化生を示す腫 瘍のうちの 8 例が局所再発し, 8 例中 7 例の初回治療 が腫瘍摘出術であったと指摘しており，線維腫症様の 表現型をもつ化生性腫場は局所再発の高リスク群であ ると述へている。化学療法に対しては腫瘍の肉腫様細 胞への化生性変化を反映して抵抗性であるとされる。 予後については見解が分かれているが，5年生存率は 62〜 67\% と報告されているい位，症例数が少なく病期 別の比較はできないが, 通常型乳癌の 5 年生存率と比 べると予後不良である.Kaufman ら"11は肉腫様成分が 多いものでは 5 年生存率 $28 \%$ で，さらに予後不良と報 告している.

本例は浸潤性乳癌としての紡錘細胞癌と非浸潤性乳 管癌が併存していた，多発乳癌の定義には統一された 見解はないが, おのおのの癌病巣に組織学的に連続性 癌浸潤のないもの ${ }^{12)}$, 病理学的にみて不連続で, お互い に乳管内病巣を有するもの列などとされ，その頻度は それぞれ $4.0 \% ， 6.5 \%$ と報告されている.しかし，こ れらには起源の異なる真の意味での多発である multicentric と，1つの癌を中心に乳管内進展などに より周囲に第 2 , 第 3 の癌巣を発する multifocal $の ~ 2$ つの考え方が含まれている。小井田ら ${ }^{(2)}$ は multicentric と multifocal の区別は困難としながら も, 副癌巣の大部分は同一あるいは近隣 quadrantに あること，主癌巣と同じ組織型であったものが73.8\% と大半を占めていることより,多発乳癌の多くは乳管 内進展による multifocal な発生であるとしている. 本 症例は隣接 quadrant であるが, 組織型は異なってお り，連続性も認めないことから multicentric であると 考えられた.治療は胸筋温存乳房切除術を施行したが, 三瀬ら ${ }^{(4)}$ は一側多発癌に対しても乳房温存療法の適応 外とすべきではないと報告している.

浸潤癌の特殊型を主癌巣とした多発乳癌の報告 ${ }^{15) 16}$ は少なく，われわれの調べた範囲では紡鏵細胞癌と非 浸潤性乳管癌の併発の報告は本例のみである.

\section{結語}

単発癌でも稀な組織型である紡鍾細胞癌と非浸潤性 乳管癌を同側同時性に併発した，多中心性発生と考え られる症例を経験した，乳癌の多発は稀でなく，本症 例の椂に特殊型の浸潤癌であっても多発乳癌の可能性 を常に念頭に置くことが重要であると考えられた。

\section{文献}

1) マンモグラフィガイドライン委屓会編：マンモグ ラフィガイドライン. 第1版, 医学書院, 東京, 1999, p21

2) 日本乳瘦学会編：臨床・病理乳癌取扱い規約. 第 13版，金原出版，東京，1996

3）坪田典之, 田聥秀幸, 谷口清英: 極めて稀な乳腺 癌肉腫と考えられた1例. 日臨外医会誌 58 ： 2005-2009, 1997

4）鈴間孝臣, 三好新一郎, 前部屋進自他：乳腺紡錘 細胞演の 2 例. 日臨外医会誌 $55: 1167-1172$, 1994

5）康 雅博, 道清 勉, 藤川正博他: 乳腺紡鏵細胞 癌の 1 例。日臨外会誌 $61: 2910-2913,2000$

6）石崎政利，秋山典夫，田中司玄文他：弤娠授乳期 乳腺紡鍾細胞癌の 1 例. 日臨外会誌 59 :25232526, 1998

7）田辺嘉高, 西原一善, 米山昌珠他: 乳腺紡鏵細胞 癌 5 例の臨床病理学的検討. 乳癌の臨 $42: 631$ 637, 1996

8）前村道生, 泉雄 勝, 石田常博他：乳腺紀錘細胞 癌の11例一とくに竞胞化傾向について一，乳癌の 臨 $36: 2167-2172,1990$

9) Wargotz ES. Deos PH, Norris HJ : Metaplastic carcinoma of breast, II. Spindle cell carcinoma. Hum Pathol 20:732-740, 1989

10) Gobbi H. Simpson JF, Borowsky A, et al: Metaplastic breast tumors with dominant fibromatosis-like phenotype have a high risk of local recurrence. Cancer $85: 2170-2182,1999$

11) Kaufman MW, Marti JR, Gallager HS, et al : Carcinoma of the breast with pseudosarcomatous metaplasia. Cancer $53: 1908-1917$, 1984

12）小井田時廣, 木村盛彦, 小川 晃地: 一側多腫痛 乳癌の臨床病理学的検討. 乳癌の臨 $10: 696-$ 700,1995

13）梶原哲郎, 喜納 勇, 秋山 太他：多中心性釈癌 の研究. 乳癌の臨 $7: 535-540,1992$

14）三瀬圭一，菅 典道, 児玉 宏：一側多発乳癌に 対する乳房温存療法の経験. 乳癌の臨 $13: 327-$ 332,1998

15）小高雅人，岡崎泰長，堀見忠司他：組織型の異な 了多中心発生の一側多発乳癌の 1 例. 日臨外会誌 $60: 380-383,1999$

16）日馬幹弘, 海瀬博史, 黄 秀雄他: 乳腺扁平上皮 癌と非浸潤性乳管癌の併存した 1 例. 日臨外医会 誌 $57: 1881-1884,1996$ 


\title{
A CASE OF SPINDLE CELL CARCINOMA WITH NON-INVASIVE DUCTAL CARCINOMA IN THE IPSILATERAL BREAST
}

\author{
Nao YOSHIDA, Yasuo HAKUTA, Takeki SUZUKI and Mayumi TANI* \\ Department of Surgery, Toride-kitasoma Medical Association Hospital \\ -Department of Breast and Endocrine Surgery, Nihon University School of Medicine
}

\begin{abstract}
We present a case of spindle cell carcinoma synchronously associated with non-invasive ductal carcinoma in the ipsilateral breast. A 54-year-old woman was seen at the hospital because of a left breast tumor. A painless left breast tumor with the diameter of $2.5 \mathrm{~cm}$ was palpated. Mammography visualized a distinctly outlined tumor $3.4 \mathrm{~cm}$ in diameter in the same area. At the same time, an ill-defined tumor $1.1 \mathrm{~cm}$ in diameter, with faint calcifications, was also recognized in the B area. Ultrasonography and dynamic magnetic resonance imaging scans of the breast revealed that the both tumors had apparently different characters. Fine needle aspiration cytology of the main foci resulted in class IIIb for that in $\mathrm{CA}$ area and class $\mathrm{V}$ for that in the $\mathrm{B}$ area. Accordingly, synchronous multiple cancer of the breast was diagnosed and a modified radical mastectomy $(\mathrm{Bt}+\mathrm{Ax})$ was carried out. Pathologically the tumor in the $\mathrm{CA}$ area was spindle cell carcinoma and the tumor in the $\mathrm{B}$ area was non-invasive ductal carcinoma. It is considered that a possibility of multiple breast cancer must be kept in mind even for specific type of non-invasive breast cancer.
\end{abstract}

